\title{
Influence of External Environmental Factors on the Success of Public Housing Projects in Developing Countries
} \author{
Aminu Musa ${ }^{3}$ \\ ${ }^{1}$ Department of Quantity Surveying, University of Technology, Malaysia \\ ${ }^{2}$ School of Management, University of Tasmania, Australia \\ ${ }^{3}$ Department of Architecture, Abmadu Bello University, Zaria, Nigeria
}

Mohammed Mukhtar Musa', Roslan Bin Amirudin', Trevor Sofield ${ }^{2}$ and Mohammed

\begin{abstract}
External environmental factors, which include political environment, economic environment and social environment, affect the success of public housing projects in developing countries. The purpose of this paper is to establish the effect of these factors on public housing project success using structural equation modelling (SEM) techniques. The study was conducted in Nigeria by means of interviews, a pilot study and a main survey. Five hundred and fifty (550) questionnaires were administered to construction professionals who work as developers, consultants or contractors and those working in public housing agencies. Two hundred and seventy-six (276) questionnaires were returned completed. The data collected were analysed by means of SEM. The results reveal that (i) the economics factor significantly affects public housing project success, (ii) the social factor significantly affects public housing project success, and (iii) the political factor significantly affects public housing project success. The study developed a comprehensive model that can assist housing policy makers, consultants, developers, contractors and other stakeholders in the planning and development of public housing programmes.
\end{abstract}

Keywords: Public housing, project success, political factor, economic factor, social factor.

Paper type: Research article

\section{Introduction}

There is general agreement that housing contributes significantly to the advancement of quality of life and general well-being of individuals (Erguden, 2001). The housing sector creates employment, reduces poverty and contributes to economic recovery and growth in many nations (Arku, 2006). Thus housing has economic, social and cultural importance. However many developing countries are experiencing rapid growth in population and urbanisation. As a result, provision of adequate housing remains a major challenge facing governments in those countries (Sivam, 2002; Bredenoord and Lindert, 2010). Despite the fact that governments have long been putting more effort into addressing this problem, little success has been recorded (Datta and Jones, 2001). It is obvious that the housing problem is more prevalent in Africa and developing parts of Asia (UN-Habitat, 2010). Bredenoord and Lindert (2010) reported that most countries in Africa, Asia and Latin America lack adequate and decent housing for the majority of their citizens. UN-Habitat (2010) reported that the urban population is rapidly increasing, especially in the developing World, and thus national governments are challenged with the major task of providing decent accommodation for their people. For instance, UN-Habitat (2013) reveals that

Copyright: Construction Economics and Building 2015. (C) 2015 Mohammed Mukhtar Musa, Roslan Bin Amirudin, Trevor Sofield and Mohammed Aminu Musa. This is an Open Access article distributed under the terms of the Creative Commons Attribution 4.0 Unported (CC BY 4.0) License (https://creativecommons.org/licenses/by/4.0/), allowing third parties to copy and redistribute the material in any medium or format and to remix, transform, and build upon the material for any purpose, even commercially, provided the original work is properly cited and states its license.

Citation: Musa, M.M., Amirudin, R.., Sofield, T. and Musa, M.A. 2015. Influence of external factors on the success of public housing projects in developing countries, Construction Economics and Building, 15(4), 30-44. DOI: http://dx.doi.org/10.5130/AJCEB.v15i4.4514 
the world's urban population in 2011 was 3.63 billion people, equivalent to $52.1 \%$ of the world's total population; this figure will increase to 6.25 billion people by the year 2050 and will represent $67.2 \%$ of the global population. In developing countries alone 5.12 billion people will be living in urban cities by 2050. Furthermore, UN-Habitat (2010) claims that by the year 2030 approximately 3 billon people worldwide, mostly from developing countries, will need decent housing with infrastructure and services. These statistics are alarming as they suggest that national governments, especially in developing countries, must put greater effort into providing additional housing for their increasing populations.

Additional mass housing production is needed each year to address the housing problem in developing countries. Moreover, because the majority of people in these countries are low income earners, it is essential to thoroughly address housing financing issues given its significant role in home ownership. Sivam (2002) argues that housing financing is not well developed in most developing countries. The formal housing financing system contributes less than $20 \%$ to housing purchases, and even though the majority of people in these countries are low incomes earners, they must pay mortgages within a short period of time and at a very high interest rate. Consequently financing for housing development more often comes from informal sources of credit. For instance, in Nigeria, interest rates range between $19 \%$ and $22 \%$ per annum (FGN, 2009). Whereas in developed countries, most families own homes through mortgages that have low down payment requirements and long- term monthly repayment periods, the lack of an effective housing financing system in developing countries makes it difficult for many families to own homes. However, there is a general consensus that to ensure a sustainable urban environment, social, economic and environmental issues of the urban development must be included in the overall urban planning framework (Bredenoord and Lindert, 2010). Nevertheless UN-Habitat (2012) reported that external environmental factors, such as social and economic aspects of housing, have not been adequately addressed in many developing countries' housing policies. Consequently, decent and affordable housing remains only a dream for the majority of people in those countries. In addition, UN-Habitat (2012) observed that public housing in developing countries is often built according to low standards and fails to consider the needs of residents; furthermore, it is often located in remote areas that lack basic infrastructure and social amenities. As a result, many public housing projects in developing countries are considered failures, which have served as the motivation behind this study. It is important to note that until recently researchers have not paid attention to assessing the influence of external factors on the success of public housing development. This paper therefore aims to establish the effect of these factors on the success of public housing project in developing countries.

\section{Concept of Project Success}

Over the last three decades a number of studies have been carried out on project success (McLeod, Doolin and MacDonell, 2012; Ika, 2009; Pinto and Slevin, 1987) nevertheless, until now, there has been no consensus among researchers regarding a standard definition of project success or standard criteria for measuring it (Baccarini, 1999; McLeod, Doolin and MacDonell, 2012). Liu and Walker (1998) assert that project success is a subject that has continuously been discussed but without significant agreement having been reached; thus the definition of project success remains vague because various stakeholders have different perceptions on its meaning, which may lead to disagreement when assessing whether a particular project is successful (De Wit, 1988). For instance, a project may be considered successful by a client, whereas an end user or contractor may perceive it as unsuccessful (Toor and Ogunlana, 2010). However, there is general agreement that project success involves both efficiency and effectiveness (Belout and Gauvreau, 2004). 
Ashley, Laurie and Jaselskis (1987) defined project success as "results much better than expected or normally observed in terms of costs, schedule, quality, safety and participants satisfaction". De Wit (1988) posits that overall project success is achieved if all of the technical performance specifications of the project have been met, and if all project team members, end users and key people in the parent organisation are highly satisfied with the outcome of the project. Earlier Pinto and Slevin (1987) argued that a project is said to be successful if it is completed on time, within budget, achieves all project goals and end users are satisfied with the project. De Wit (1988) explained that a project might be successful even though the performance of project management is poor. However, good project management can contribute to the achievement of a successful project outcome, but it cannot prevent failure. Thus, from all of these definitions, there is agreement among researchers that project success involves participants' satisfaction and meeting the project goals. On the other hand, Cooke-Davies (2002) distinguishes between project success and project management success. Project success addresses the achievement of overall project objectives, while project management success measures project management performance of time, cost and quality. Similarly, Lim and Mohamed (1999) explained two different viewpoints in relation to project success, namely the micro viewpoint of project success and the macro viewpoint. The macro viewpoint concerns the achievement of original project goals, which can only be known after the project's completion at the operational stage. On the other hand, the micro viewpoint of project success concerns project management success in terms of achievement at the construction phase. Traditionally, project success measures are on schedule, within budget (cost) and specified quality (Westerveld, 2003; Atkinson, 1999). However, projects have often been completed on time, within budget and to specified quality but have been considered to failures, whereas some projects have exceeded their time and cost constraints and are considered successful (Ika, 2009; Lim and Mohamed, 1999; De Wit 1988). Therefore, the criteria for measuring project success go beyond the traditional measures of time, cost and quality; other criteria also have to be used, such as client satisfaction, end user satisfaction, environmental impact of the project, and so on.

\section{Project Success Criteria}

Cooke-Davies (2002) defined success criteria as measures by which success or failure of a project will be judged. Earlier Lim and Mohamed (1999) defined success criteria as set of principles or standards by which success can be judged. Toor and Ogunlana (2009) suggest the following criteria for measuring success: project completion on time, within budget and to specified quality; safety, efficiency, effectiveness, free from defect, meets stakeholders' expectations, and minimal construction disputes and conflicts. Atkinson (1999) classified success criteria into two measures - success at the delivery stage and success at post-delivery stage. The success criteria at the delivery stage include cost, time and quality and are referred to as iron triangle. These criteria measure the efficiency of project management or project management success. On the other hand, the project success criteria at the post-delivery stage are divided into product success criteria and organisational success criteria. The product success criteria include end user satisfaction, environmental impact, contractors' profit, team members' satisfaction, etc., while the organisational success criteria are the benefit to the organization, which includes improved efficiency, improved effectiveness, increased profits, reduced waste and promotion of organisational learning. Lim and Mohamed (1999) divide the concept of project success into the macro and micro viewpoints. The macro viewpoint concerns the achievement of the original project goals, which can only be known after the project's completion at the operational stage. The criteria for measuring project success at the macro viewpoint are completion on time, client satisfaction, end user satisfaction and stakeholder satisfaction. Conversely, the micro viewpoint of project success concerns project management success, i.e., achievement at the construction phase. The criteria for measuring project success at the micro point of view are completion on 
time, within budget, to the specified quality standard and safety. This means that the micro viewpoint concerns project success over a short period, while the macro viewpoint of project success concerns project success over a long period. Furthermore Ahadzie, Proverbs and Olomolaiye (2008) identify 15 critical success criteria for mass housing projects, which they classified into four components as follows: environmental impact, customer satisfaction, overall cost and time, and quality. Sanvido et al. (1992) proposed the following criteria for measuring project success, depending on a particular stakeholder's perspectives (client, end user, contractor or consultant). The criteria are project completed on budget, on schedule and to specified quality; client satisfaction; end user satisfaction; pleasing aesthetics; product marketability; safety; and minimal or no claims or conflicts.

Therefore, from this review, it can be noted that criteria for project success is beyond the traditional measures of time, cost and quality, which mainly measures project management success; however, additional criteria emerge that include end user satisfaction, stakeholder satisfaction, safety, environmental impact and minimal disputes or the absence of any legal proceedings. Based on the literature review carried out above, this study used the following criteria to measure the success of public housing projects: project completed on time, project completed within budget, project completed to specified quality standard, client satisfaction, end user satisfaction, project team member satisfaction, project completed with low accident rate, minimal or no legal claims or proceedings, environmental impact of the housing project, aesthetic appearance of the housing units and meeting the project's goals.

\section{Project Success Factors}

Lim and Mohamed (1999) defined success factors as any circumstances, fact or influence that contributes to the success or failure of a project. Cooke-Davies (2002) added that success factors are those factors that contribute to successful project outcomes.

A number of studies have been conducted to identify factors that influence the success of projects (Pinto and Slevin, 1987; Belassi and Tukel, 1996; Lim and Hwang, 2013). Belassi and Tukel (1996) developed a framework for critical success factors of projects. They classify the factors into four groups, factors related to the project, factors related to the project manager and team members, factors related to the organisation, and factors related to the external environment. Variables that measure external environmental factors include the political environment, economic environment and social environment. Gudiené et al. (2013) developed a conceptual critical success factor model for construction projects. The identified factors were classified into seven main groups, namely, external factors, institutional factors, project related factors, factors related to project management and team members, factors related to project managers, factors related to clients, and factors related to contractors. The variables measuring external factors include the political environment, economic environment and social environment, among others. Hyvri (2006) studied project success factors in different organisational conditions. He classified the factors into five groups, namely, factors related to the project, factors related to the project manager/leadership, factors related to the project team members, factors related to the organisation and factors related to the environment. Variables that measure factors related to the environment include the political environment, economic environment and social environment. Chan, Scotto and Chan (2004) developed a conceptual framework for factors affecting construction project success. The identified factors have been classified into five groups, namely, project management actions, project related factors, human related factors, project procedure and the external environment. Variables under the external environment include the political environment, economic environment and social environment.

Gudienè et al. (2013) defined external environmental factors as those factors affecting the success of construction projects, which are mostly beyond the control of the management team. 
These factors include political, economic and social factors (Belassi and Tukel, 1996). Political factors concern political stability and government intervention in providing both incentives and enabling environments for public housing development (Chen et al., 2012). Government has an important role to play in ensuring the success of public housing in terms of infrastructure development, provision of a favourable legal framework, and guarantees to developers. Pugh (2001) argues that failure on the capability of government will affect the success of overall housing sector development. Economic factors constitute the economic environment that influences the flow of funds and affordability in financing. These include a stable macroeconomic environment, availability of credit facilities, low interest rates and long repayment periods (Gudienè et al., 2013). Failure of the housing financing system seriously affects the success of the housing sector (Pugh, 2001). Social factors have been concerned with the issues of the cultural aspect, health consideration and the general life style of occupants (Gudienè et al., 2013).

Zhang (2005) identified a stable political system, favourable economic system, adequate financial market, predictable currency exchange risk, low interest rate, long-term debt financing, a favourable legal framework and government support, as critical to the success of PPP projects. $\mathrm{Li}$ et al., (2005) identified good governance, a favourable legal framework, governmental involvement through the provision of guarantees, available financial market, political support, a sound economic policy and a stable macro-economic environment as critical factors to the success of PPP construction projects. Other factors identified as critical success factors for construction projects include adequate funding (Hwang and Lim, 2013; Nguyen, Ogunlana and Lan, 2004), end user involvement (Nguyen, Ogunlana and Lan, 2004; Fortune and White, 2006; Ihuah, Kakulu and Eaton, 2014), good project location (Chen et al., 2012; Chua, Kog and Loh, 1999; Ihuah, Kakulu and Eaton, 2014), appropriate design (Turcotte and Geiser, 2010), accessible credit facility, Gudiene et al. (2013) and low down payment requirements (UNHabitat, 2011).

Based on the literature review presented above, this study proposes the following hypotheses:

- H1: Economic factor has significant influence on public housing project success

- H2: Social factor has significant influence on public housing project success

- H3: Political factor has significant influence on public housing project success

The hypothetical model for the relationship between critical success factors and public housing project success is presented in Figure 1, while Table 1 presents the observed variables of each construct.

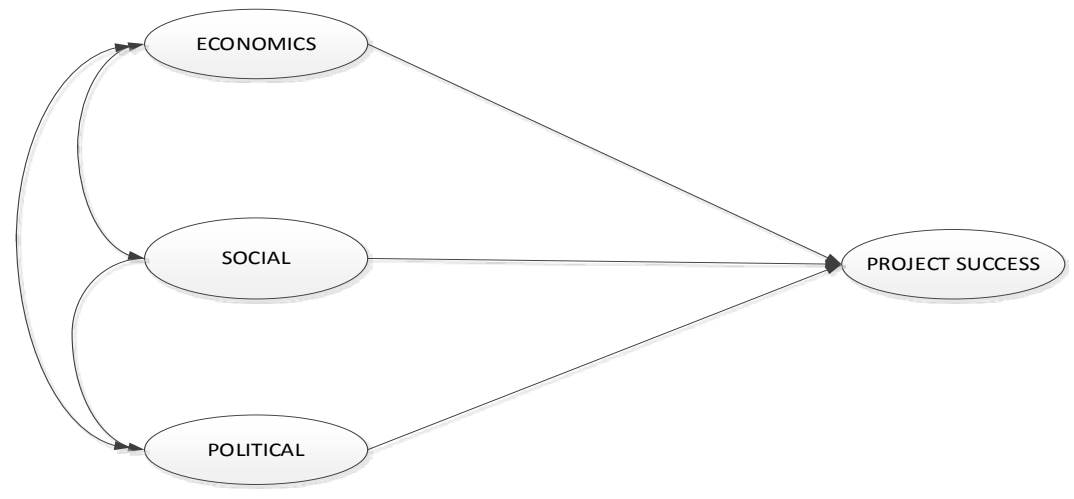

Figure 1: Hypothetical Model 
Examination of Table 1 indicates that the observed variables of the constructs are highly relevant to developing countries. For instance, economic factor constitutes the economic environment that influences the flow of funds and affordability in financing. In developing countries, where the majority of the population are low income earners, it will be very difficult for them to save money for housing development. Thus, they rely on the availability of long-term loans for housing financing with low lending interest rates. Similarly, social factor concerns issues of culture, health and the general life style of the occupants. In most developing countries, the issue of culture is very important, so end user involvement at the early design stage will help in producing an acceptable design. Likewise, because the end users are low income earners, location of housing units is imperative not only because of health issues, but because consideration should be made in terms of accessibility to public transportation and other public institutions. Political factor concerns government support and provision of an enabling environment. However in most developing countries there is fear of uncertainty in the economic and political environment. Therefore governments need to provide guarantees to developers in terms of risk management, where the government is best able to manage them. An example of such risks is fluctuation of exchange rates, which is common in those countries. In addition, because public housing projects in most developing countries are social housing schemes, government should provide land and infrastructure to make the completed housing affordable to low income earners, which is the objective of public housing schemes.

Table 1: Constructs and indicators

\begin{tabular}{|c|c|c|}
\hline Construct & & Indicators \\
\hline \multirow[t]{6}{*}{ Economic Factor } & EC1 & Stable macro-economic environment \\
\hline & EC2 & Accessible credit facilities to target beneficiaries \\
\hline & EC3 & Low interest rate \\
\hline & EC4 & Implementation of sound economic policy \\
\hline & EC5 & Long- term loan repayment period \\
\hline & EC6 & Low down payment requirement \\
\hline \multirow[t]{4}{*}{ Social Factor } & SO1 & Good project location \\
\hline & SO2 & Appropriate design \\
\hline & SO3 & End user involvement in the project \\
\hline & SO4 & Flexibility of design and construction \\
\hline \multirow[t]{7}{*}{ Political Factor } & PO1 & Stable political environment \\
\hline & PO2 & Government support in public housing projects \\
\hline & PO3 & Government guarantees to developers \\
\hline & PO4 & Favourable legal framework \\
\hline & PO5 & Provision of secured land by the government \\
\hline & PO6 & Adequate funding of infrastructure development \\
\hline & PO7 & Government support for local building materials manufacturers \\
\hline \multirow[t]{12}{*}{ Success Criteria } & SC1 & Project completed on time \\
\hline & SC2 & Project completed within budget \\
\hline & SC3 & Project completed to the specified quality standard \\
\hline & SC4 & Client satisfaction with the project \\
\hline & SC5 & End user satisfaction with the project \\
\hline & SC6 & Project team member satisfaction \\
\hline & SC7 & Project completed with a low accident rate. \\
\hline & SC8 & Absence of any legal claims or proceedings \\
\hline & SC9 & Environmental impact of the housing project \\
\hline & SC10 & Marketability of the housing units \\
\hline & SC11 & Aesthetic appearance of the housing units \\
\hline & SC12 & Meeting the project's purpose \\
\hline
\end{tabular}




\section{Methodology}

The research was performed in Nigeria and consisted of three phases: interviews, a pilot survey and a main survey. Initially, an intensive literature review was carried out to identify external factors and their associated variables that influence the success of public housing projects. As a result of the literature review, a list of factors and their variables was developed. Subsequently, face-to-face interviews were conducted with ten experts in the housing sector. The experts were academic experts and construction professionals who had at least 15 years of experience working with public housing projects.

At the beginning of the interviews, the participants were presented with a list of the factors and their indicators as identified from the literature, and were asked to state their opinions on whether they considered the factors and their corresponding indicators relevant and critical to the success of public housing projects in developing countries. They were also asked to suggest additional variables that they considered relevant but were not mentioned in the list. However, regardless of whether an interviewee agreed with a particular factor being critical, he or she was asked to state a reason. The participants' profile and their views regarding the influence of the factors on the success of public housing projects were recorded. As a result of the interviews some variables were reworded, and three new variables were added to the list. The modified and the additional variables were used to design the main questionnaire. The questionnaire was designed for respondents to assess the influence of each factor on the success of public housing projects using a Likert scale ranging from 1 to 5 , where 1 represented a factor that is not important and 5 represented an extremely important factor. The respondents were also asked to assess the criteria for measuring success using the same scale. A total of five hundred and fifty (550) questionnaires were administered to construction professionals using the purposive sampling method. The target population was developers, contractors, consultants, and those working in public housing agencies. Two hundred and seventy-six (276) questionnaires were returned completed, representing a $50.2 \%$ response rate.

\section{Data Analysis and Results}

The analysis of the interviews was conducted through narrative analysis. The results obtained indicated that the participants agreed that all factors identified from the literature review have a strong impact on the success of public housing projects in developing countries. However, they suggested three additional variables that were not mentioned in the initial list presented to them. These additional variables were 'flexibility of design and construction', 'provision of land with secure tenure by the government', and 'government support to local building materials manufacturers'. The interviewees argued that it is imperative to allow for flexibility in the design and construction of public housings because end users may come from different socio-economic and cultural backgrounds. It may be impractical to incorporate the cultural heritage of all of the different ethnic groups in the design. Moreover, the economic status and the family size of the occupants may increase in the future. Thus, if the design and construction of the housing units are flexible, the end users can make changes in the layout and design of their homes to meet their respective requirements as the need arises. The interviewees also argued that in most developing countries, the process of acquiring land and land registration is very frustrating, time consuming and expensive; hence, they suggested that if the government provides land with secured tenure to developers of public housing, the cost of the completed housing will decrease, thereby making homes more affordable to low income earners. Furthermore, the interviewees argued that government support for local building materials manufacturers is critical to the success of public housing projects because many developing countries depend greatly on imported building materials and components despite the presence of abundant resources in those countries. They added that if the government supports local building materials 
manufacturers by creating an enabling environment, this will attract more investors to the sector. Consequently, a high percentage of materials for housing development could be produced locally, and more cheaply than imported ones. This will make public housing more affordable for low income earners.

Regarding the questionnaire survey; of the 276 respondents, 84 work in the public sector, 62 are developers, 63 are consultants and 67 are contractors. Table 2 shows a summary of the respondents' profiles in terms of their professional affiliation, highest academic qualification, years' experience in working with public housing projects and types of organisation. Based on their experience and academic qualification, the respondents were considered able to provide reliable information.

Table 2: Summary of respondents' profile

\begin{tabular}{|l|l|l|l|l|l|l|l|}
\hline Profession & $\%$ & Qualification & $\%$ & $\begin{array}{l}\text { Experience } \\
\text { (years) }\end{array}$ & $\%$ & Organisation & $\%$ \\
\hline Architecture & 28.6 & HND & 19.2 & $1-5$ & 5.1 & Public Sector & 30.4 \\
\hline Quantity Surveying & 30.8 & BSC & 49.3 & $6-10$ & 30.8 & Developer & 22.5 \\
\hline Engineering & 15.9 & MSC & 26.1 & $11-15$ & 36.6 & Consultancy & 22.8 \\
\hline Building Technician & 22.5 & PHD & 1.8 & $16-20$ & 18.8 & Contracting & 24.3 \\
\hline Others & 2.2 & Others & 3.6 & $>20$ & 8.7 & & \\
\hline
\end{tabular}

The data collected were analysed using structural equation modelling techniques with SPSS Amos software version 22. The estimation of parameters was carried out using the maximum likelihood estimation method. Initially, confirmatory factor analysis was performed to test the validity of the measurement model. After the evaluation of the standardised factor loading of the observed variables, standardised residual covariance and modification indices, the initial measurement model was modified as recommended by Kline (2011) and Byrne (2010). However, the details process of the modification has not been reported because of the limitation of space. Specifically, the modification is as follows: two variables (project team members' satisfaction and marketability of housing units) were deleted because their standardised residual values were large i.e. $>2.56$. In addition, one variable (implementation of sound economic policy) was deleted because its standardised factor loading was less than 0.5. Furthermore, two parameters were added to the model because two errors' covariance have a large modification index and their corresponding items measure the same construct as shown in Figure 2. Subsequently, the structural relationship among latent construct was tested.

Convergent validity of the measurement model was assessed using construct reliability and standardised factor loading of the observed variables as suggested by Sekaran and Bougie (2009), and the results are presented in Table 5. Notably, all standardised factor loadings are greater than 0.5 , indicating that the observed variables measure their corresponding factors well. Cronbach alpha was used to assess the reliability of the constructs, as shown in Table 5; the values range between 0.65 and 0.87 , meaning that they are all satisfactory. Thus, based on these results, the convergent validity of the model is confirmed.

The fit indices for the final measurement model and that of the structural model are presented in Table 3. The results indicate that all of the goodness of fit measures are within the recommended cut off values suggested by Hair et al. (2009). The ratio of chi square and degree of freedom is 1.412, the goodness of fit index (GFI) is 0.94, the Root Mean Residual (RMR) is 0.024, the Comparative Fit Index (CFI) is 0.94, the Tucker-Lewis index (TLI) is 0.93 and the Root Means Square Error of Approximation is 0.039 . These indicate that the model adequately fits the sample data. 
Table 3: Fit indices of the structural model

\begin{tabular}{llll}
\hline Fit Indices & Recommended & $\begin{array}{l}\text { Measurement } \\
\text { Model }\end{array}$ & Structural Model \\
\hline $\mathrm{X}^{2} / \mathrm{df}$ & $<3.0$ & 1.412 & 1.412 \\
$\mathrm{GFI}$ & $>0.9$ & 0.904 & 0.904 \\
$\mathrm{RMR}$ & $>0.08$ & 0.024 & 0.024 \\
$\mathrm{CFI}$ & $>0.9$ & 0.941 & 0.941 \\
TLI & $>0.9$ & 0.934 & 0.934 \\
RMSEA & $<0.08$ & 0.039 & 0.039 \\
\hline
\end{tabular}

Table 4 shows standardised and un-standardised regression weight of the structural model. Notably, all of the three hypotheses have been supported, that is, the parameter estimates are all significant. This means that all of the three external factors significantly influence the success of public housing projects in developing countries. However, the economic factor has the highest impact on public housing project success, with standardised estimates of 0.413 , followed by the social factor (0.237), and the political factor (0.193). In other words, for 1 level increase in standard deviation on the economic factor, there would be a 0.413 increase in standard deviation on project success, all other variables being controlled. The other results can be interpreted similarly. Figure 2 indicates the final research model with the parameters indicated.

Table 4: Structural Path Estimates

\begin{tabular}{lllll}
\hline & Standardised & Unstandardised & C.R & P \\
\hline Economic $\rightarrow$ Success & 0.413 & 0.447 & 3.922 & Sig \\
Social $\rightarrow$ Success & 0.237 & 0.282 & 2.947 & Sig \\
Political $\rightarrow$ Success & 0.193 & 0.228 & 2.062 & Sig \\
\hline
\end{tabular}

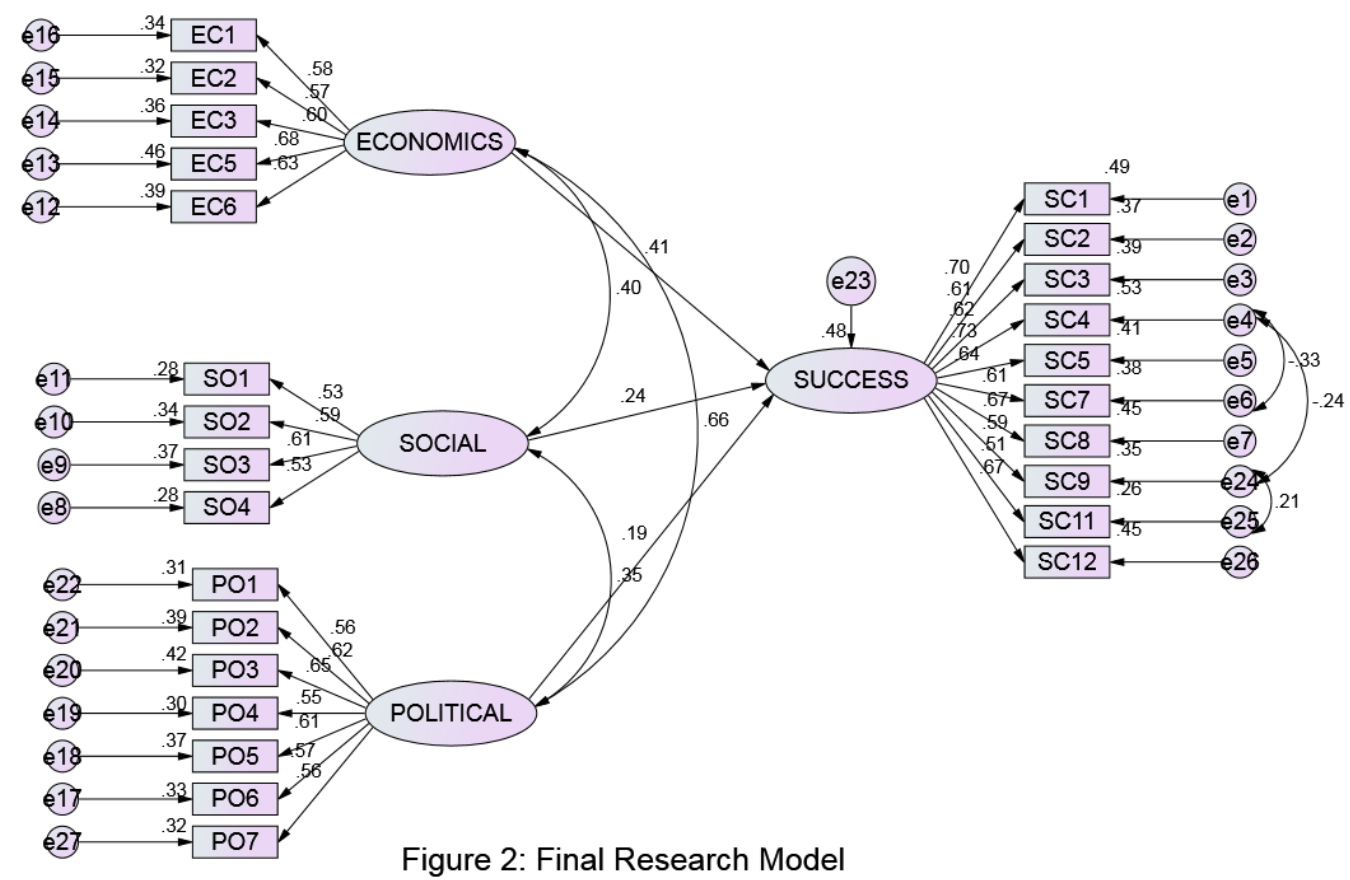


Table 5: Standardised and reliability coefficient estimates of the final SEM.

\begin{tabular}{|c|c|c|}
\hline Factor & Standardised Estimates & Construct Reliability \\
\hline EC1 ECONS & .584 & .748 \\
\hline $\mathrm{EC} 2 \longleftarrow \mathrm{ECONS}$ & .566 & \\
\hline $\mathrm{EC} 3 \leftarrow$ ECONS & .600 & \\
\hline EC4 ECONS & .676 & \\
\hline EC5๘ ECONS & .627 & \\
\hline SO1 SOCIAL & .530 & .651 \\
\hline SO2 $\longleftarrow$ SOCIAL & .585 & \\
\hline SO3 SOCIAL & .611 & \\
\hline 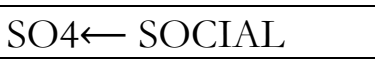 & .531 & \\
\hline PO1 $\leftarrow$ POLITICAL & .561 & .788 \\
\hline PO2 $\longleftarrow$ POLITICAL & .621 & \\
\hline PO3 $\leftarrow$ POLITICAL & .649 & \\
\hline 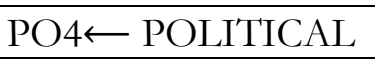 & .549 & \\
\hline PO5๘ POLITICAL & .609 & \\
\hline PO6 & .574 & \\
\hline PO7£ POLITICAL & .561 & \\
\hline SC1 & .699 & .869 \\
\hline SC2 $\leftarrow$ SUCCESS & .606 & \\
\hline SC3 $\leftarrow$ SUCCESS & .624 & \\
\hline SC4 SUCCESS & .726 & \\
\hline SC5 SUCCESS & .641 & \\
\hline SC6 $\leftarrow$ SUCCESS & .614 & \\
\hline SC7 $\leftarrow$ SUCCESS & .669 & \\
\hline SC8 & .588 & \\
\hline SC9 SUCCESS & .514 & \\
\hline SC10 $\leftarrow$ SUCCESS & .667 & \\
\hline
\end{tabular}

\section{Discussion}

The results from this study reveal that, first of all, there is significant relationship between economic factor and public housing project success (H1 is accepted). The result is consistent with that of UN-Habitat (2011) and Chen et al. (2012), who emphasise the importance of economic factor on project success. Measures of economic factor include a stable economic environment, accessible credit facilities, low interest rate, a long-term loan repayment period and a low down payment requirement. Thus, the government should ensure a stable economic environment to encourage the private sector to invest in public housing projects, as many investors will not participate in uncertain economic conditions. Li et al. (2005) noted that a stable economic environment plays an important role in mitigating risk for the private sector. Accessibility of long- term loans at low interest rates is essential in most developing countries, as the majority of their populations are low income earners who cannot save money for homes. Therefore they rely on available credit to own decent housing. In addition, a long repayment period is vital to many households, as low income earners will find it difficult to repay mortgages 
in short periods. Furthermore, low interest rates on loans will make housing more affordable to low income earners. In some developing countries like Nigeria, the interest rate can be $22 \%$ or higher. This makes housing beyond the reach of most people. Okonjo-Iweala (2014) reported that the lack of appropriate housing finance mechanisms creates a situation whereby many Nigerians who do have large amounts of money up front to buy housing outright are unable to own decent homes. Earlier Erguden (2001) revealed that a lack of an effective housing financing system is a major constraint for low income housing delivery in developing countries.

The results also confirm that the social factor is significantly related to public housing project success. The variables of social factor are good project location, appropriate design, flexibility of design and construction, and end user involvement. The findings are in consistent with those of Ihuah, Kakulu and Eaton (2014), Turcotte and Geiser (2010), and Nguyen, Ogunlana and Lan (2004). These findings mean that public housing should be built in a good location in a safe and healthy environment. In addition, because the residents are low income earners, housing should also be located where there is easy access to public transportation, work places, commercial establishments and essential public institutions such as schools and hospitals. Chen, Sebstad and O'Connell (1999) argued that site limitation and location are the important attributes that affect quality performance in construction projects. On the other hand, Turcotte and Geiser (2010) assert that housing should be designed to provide adequate space, lighting and ventilation and provide respect for occupants. These results also suggest that the design of housing should be flexible and adaptable to allow occupants to make changes to the layout of their homes to meet their future needs following an increase in family size or economic status, or to depict their cultural heritage. This is in line with the findings of Ihuah, Kakulu and Eaton (2014), which suggest that cultural differences in Nigeria influence the end users in choosing a particular housing type. In the same publication, emphasis has been placed on the importance of end user involvement in the design and management of public housing projects.

The study also found that political factor has a direct effect on project success, and the relationship is significant. Measures of political factor are a stable political environment, government support for public housing, government guarantees, a favourable legal framework, provision of land with secure tenure, adequate funding of infrastructure by the government and finally, government support for local building materials manufacturers. This result is consistent with that of Hwang and Lim (2013) and Cheung, Chan and Kajewski (2012) who stress the importance of a stable political environment in successful implementation of projects. To encourage the private sector to invest in public housing projects, the government should provide a guarantee to developers by managing those risks that the government is in the best position to handle, such as fluctuation of the exchange rate and changes in law. Furthermore, the result also suggests that the government should create a favourable legal framework that will facilitate the private sector's participation in public housing projects without undue restriction. This assertion is consistent with the findings of Zhang et al. (2005) who assert that the government should create a legal and economic environment in public projects to encourage the private sector to invest without fear of risk. This study also emphasises the importance of the government's provision of land and infrastructure for public housing development. This finding is consistent with that of Ihuah, Kakulu and Eaton (2014) who found land issues (accessibility and ease of registration) as critical to the success of social (public) housing in Nigeria. Land is an essential component for housing development; difficulty associated with the acquisition of land has been regarded as a major obstacle to home ownership in developing countries (Udechukwu, 2008). Thus it is essential for the government to provide land for public housing projects. This will encourage private sector participation and reduce the cost of completed housing units. On the other hand, Erguden (2001) stated that there is inadequate supply of infrastructure in most developing countries and that this is a major constraint to low income housing delivery. Moreover, Makinde (2013) noted that the cost of infrastructure, such as roads, water and 
electricity supply and sewage system constitutes a high percentage of the total cost of housing development. Thus, government provision of adequate funding for infrastructure development will also make the price of the housing more affordable to low income earners. Finally, this study reveals that government support for local building materials manufacturers is crucial to the success of public housing development in developing countries. This is consistent with Ihuah, Kakulu and Eaton (2014) who found that sustainable social housing (public housing) provision requires the utilisation of local building materials, which are in abundant supply in many developing countries. This should be explored by the private sector and the government, for sustainability. The cost of these materials is lower than the cost of imported ones. Thus the use of locally produced building materials will make public housing more affordable for low income earners. On the whole, this study found that the economic factor, social factor and political factor have a direct effect on the success of public housing projects in developing countries and that the relationships are significant. These factors should be given adequate attention in the formulation of housing policies and in the planning and development of public housing projects in developing countries.

\section{Conclusion}

Public housing project success depends on the influence of several external factors, some of which are within the control of project management teams while others are not. The aim of this paper was to establish the effects of economic, social and political factors on public housing project success. The results indicate that effective financial system, appropriate design and location and government support, significantly influence the success of public housing projects in developing countries. The study developed a model that can guide housing policy-makers and project management team members to implement a successful public housing scheme. The variables of these factors suggest that while social factor can be addressed by both the government and project team members, political and economic factors can only be controlled by the government. Furthermore, it has been explained that project success has two components, which are project management success and product success. Project management success is concerned with the achievement of project management objectives. On the other hand, product success is concerned with the achievement of overall project objectives (Baccarini, 1999). From the findings of this study it can be argued that social factor and economic factor can strongly influence product success because appropriate design and good location (social factor) have a strong impact on end users' satisfaction and general well-being. Similarly, an effective financial system (economic factor) is essential with regard to flow of incomes and affordability of the completed housing units. Conversely, it can be asserted that social factor and political factor can affect project management success. For instance, the complexity of design and bad location (social factor) can have a strong impact on the success of project management. In addition, because public housing projects are usually funded or subsidised with public funds, an unstable political environment (frequent changes of government) can affect the project implementation, which may lead to delays in completion and cost overruns. Thus these three factors should be given adequate attention in the formulation and implementation of housing policies in developing countries. Future research should examine the interrelationship between these factors. 


\section{References}

Ahadzie D., Proverbs, D. and Olomolaiye, P., 2007. Critical success criteria for mass housing building projects in developing countries. International Journal of Project Management, 26(6), pp.675-87. doi: http://dx.doi.org/10.1016/j.ijproman.2007.09.006

Arku, G., 2006. The housing and economic development debate revisited: economic significance of housing in developing countries. Journal of Housing and Built Environment, 21, pp.377-95. doi: http://dx.doi.org/10.1007/s10901-006-9056-3

Ashley, D.B., Laurie, C.S. and Jaselskis, E.J., 1987. Determinants of construction project success. Project Management Journal, 18(2), pp.69-79.

Atkinson, R., 1999. Project management: cost, time and quality, two best guesses and a phenomenon, it is time to accept other success criteria. International Journal of Project Management, 17(6), pp.337-42. doi: http://dx.doi.org/10.1016/S0263-7863(98)00069-6

Baccarini, D., 1999. The Logical Framework Method for defining Project Success. Project Management Journal, 30(4), pp.25-32.

Belassi, W. and Tukel, O.I., 1996. A new framework for determining critical success/failure factors in projects. International Journal of Project Management, 14(3), pp.141-51. doi: http://dx.doi.org/10.1016/0263-7863(95)00064$\mathrm{X}$

Belout, A. and Gauvreau, C., 2004. Factors influencing the project success: the impact of human resource management. International Journal of Project Management, 22, pp.1-11. doi: http://dx.doi.org/10.1016/S02637863(03)00003-6

Bredenoord, J. and Lindert, P., 2010. Pro-Poor Housing Policies: Rethinking the Potential of Assisted Self- Help Housing. Habitat International, 34, pp.278-87. doi: http:/ /dx.doi.org/10.1016/j.habitatint.2009.12.001

Byrne, B.M., 2010. Structural Equation Modeling with AMOS: Basic Concepts, Applications, and Programming, 2nd ed. New York: Routledge.

Chan, A.P.C., Scott, D. and Chan, A.P.L., 2004. Factors affecting the success of a construction project. Journal of Construction Engineering and Management, 130(1), pp.153-5. doi: http://dx.doi.org/10.1061/(ASCE)07339364(2004)130:1(153)

Chen, M., Sebstad, J. and O’Connell, L., 1999. Counting the invisible workforce: The case of homebased workers. World Development, 27(3), pp.603-10. doi: http://dx.doi.org/10.1016/S0305-750X(98)00154-5

Chen, Y.Q., Zhang, Y.B., Liu J.Y. and Mo, P., 2012. Interrelationships among Critical Success Factors of Construction Projects Based on the Structural Equation Model. Journal of Management in Engineering, 28(3), pp.243-51. doi: http://dx.doi.org/10.1061/(ASCE)ME.1943-5479.0000104

Cheung, E., Chan, A.P. and Kajewski, S., 2012. Factors Contributing to Successful Public Private Partnership Projects: Comparing Hong Kong with Australia and the United Kingdom. Journal of Facilities Management, 10(1), pp.45-58. doi: http://dx.doi.org/10.1108/14725961211200397

Chua, D.K.H., Kog, Y.C. and Loh, P.K., 1999. Critical Success Factors for Different Project Objective. Journal of Construction Engineering and Management, 125(3), pp.142-50. doi: http://dx.doi.org/10.1061/(ASCE)07339364(1999)125:3(142)

Cooke-Davies, T., 2002. The real success factors on projects. International Journal of Project Management, 20, pp.185-90. doi: http://dx.doi.org/10.1016/S0263-7863(01)00067-9

Datta, K. and Jones, G.A., 2001. Housing and finance in developing countries: invisible issues on research and policy agendas. Habitat International, 25, pp.333-57. doi: http://dx.doi.org/10.1016/S0197-3975(00)00038-2

De Wit, A., 1988. Measurement of project Success. Journal of Project Management, 6(3), pp.164-70. doi: http://dx.doi.org/10.1016/0263-7863(88)90043-9

Erguden S., 2001. Low-Cost Housing: Policies and Constraints in Developing Countries. International Conference on Spatial Information for Sustainable Development. Nairobi, Kenya, 2-5 October 2001.

Fortune, J. and White, D., 2006. Framing of project critical success factors by a systems model. International Journal of Project Management, 24, pp.53-65. doi: http://dx.doi.org/10.1016/j.ijproman.2005.07.004

Gudiené, N., Banaitis, A., Banaitienė, N. and Lopes J., 2013. Development of a Conceptual Critical Success Factors Model for Construction Projects: a Case of Lithuania. 11th International Conference on Modern Building Materials, 
Structures and Techniques, MBMST 2013 Lithuania: Procedia Engineering, 57, pp. 392-97. doi: http://dx.doi.org/10.1016/j.proeng.2013.04.051

Hwang, B.G. and Lim, E.J., 2013. Critical Success Factors for Key Project Players and Objectives: Case Study of Singapore. Journal of Construction Engineering and Management, 139(2), pp.204-15. doi: http://dx.doi.org/10.1061/(ASCE)CO.1943-7862.0000597

Hyvari, I., 2006. Success of Projects in Different Organizational Conditions. Project Management Journal, 37(4), pp.31-41.

Ihuah, P.W., Kakulu, I.I. and Eaton, D., 2014. A review of Critical Project Management Success Factors (CPMSF) for sustainable social housing in Nigeria. International Journal of Sustainable Built Environment. Available at: http://dx.doi.org/10.1016/j.ijsbe.2014.08.001 [Accessed 20 February 2015]. doi: http://dx.doi.org/10.1016/j.ijsbe.2014.08.001

Ika, L.A., 2009. Project Success as a Topic in Project Management Journals. Project Management Journal, 40(4), pp.6-19. doi: http://dx.doi.org/10.1002/pmj.20137

Kline, R.B., 2011. Principles and Practice of Structural Equation Modeling, 3rd ed. New York: The Guilford Press.

Lim, C.S. and Mohamed, M.Z., 1999. Criteria of project success: an exploratory re-examination. International Journal of Project Management, 17(4), pp.243-8. doi: http://dx.doi.org/10.1016/S0263-7863(98)00040-4

Li, B., Akintoye , A., Edwards, P. J. and Hardcastle, C., 2005. Critical Success Factors for PPP/PFI Projects in the UK Construction Industry. Construction Management and Economics, 23(5), pp.459-71. doi: http://dx.doi.org/10.1080/01446190500041537

Liu, A.M.M. and Walker, A., 1998. Evaluation of project outcomes. Construction Management and Economics, 16, pp.209-19. doi: http://dx.doi.org/10.1080/014461998372493

Makinde, O.O., 2013. Housing delivery system, need and demand. Journal of Environment, Development and Sustainability: DOI 10.1007/s10668-013-9474-9 [Accessed February 2014].

McLeod, L., Doolin, B. and MacDonell, S.G., 2012. A Perspective-Based Understanding of Project Success. Project Management Journal, 43(5), pp.68-86. doi: http://dx.doi.org/10.1002/pmj.21290

Nguyen, L.D., Ogunlana, S.O. and Lan, D.T., 2004. A study on project success factors on large construction projects in Vietnam. Engineering Construction and Architectural Management, 11(6), pp.404-13. doi: http://dx.doi.org/10.1108/09699980410570166

Okonjo-Iweala, N., 2014. Unleashing the Housing Sector in Nigeria and in Africa. 6th Global Housing Finance Conference. Washington, DC, U.S.A, 28 May 2014.

Pinto J. K. and Slevin, D.P., 1987. Critical Factors in Successful Project Implementation. IEEE Transaction on Engineering Management, 34(1), pp.22-7. doi: http://dx.doi.org/10.1109/TEM.1987.6498856

Pugh, C., 2001. The Theory and Practice of Housing Sector Development for Developing Countries. Housing Studies, 16(4), pp.399-423. doi: http://dx.doi.org/10.1080/02673030120066527

Savindo, V., Grobler, F., Parfitt, K., Guvenis, M. and Coyle, M., 1992. Critical success factors for construction projects. Journal of Construction Engineering and Management, 118(1), pp.94-111. doi: http://dx.doi.org/10.1061/(ASCE)0733-9364(1992)118:1(94)

Sekaran, U. and Bougie, R., 2009. Research Methods for Business: A Skill Building Approach. 5th ed. Chichester: John Wiley \& Sons Ltd.

Sivam, A., 2002. Constraints affecting the efficiency of the urban residential land market in developing countries: a case study of India. Habitat International, 26, pp.523-37. doi: http://dx.doi.org/10.1016/S0197-3975(02)00025-5

Toor, S.R. and Ogunlana, S.O., 2009. Construction professionals' perception of critical success factors for largescale construction projects. Construction Innovation, 9(2), pp.149-67. doi: http://dx.doi.org/10.1108/14714170910950803

Turcotte, D.A. and Geiser, K., 2010. A Framework to Guide Sustainable Housing Development. Housing and

Society, 37(2), pp.87-117. doi: http://dx.doi.org/10.1080/08882746.2010.11430582

Udechukwu, C.E., 2008. Obstacles to individual home ownership in Nigeria. International Journal of Housing

Markets and Analysis, 1(2), pp.182-94. doi: http://dx.doi.org/10.1108/17538270810877790 
UN-Habitat, 2010. A Practical Guide for Conducting Housing Profiles. Nairobi: United Nations Centre for Human Settlements.

UN-Habitat, 2011. Affordable Land and Housing in Africa. Nairobi: United Nations Human Settlements Programme.

UN-Habitat, 2012. Sustainable Housing for Sustainable Cities: A Policy Framework for Developing Countries. Nairobi: United Nations Centre for Human Settlements.

UN-Habitat, 2013. UN-Habitat Global Activities Report 2013. Nairobi: United Nations Centre for Human Settlements.

Westerveld, E., 2003. The project excellence model: linking success criteria and critical success factors. International Journal of Project Management, 21, pp.411-18. doi: http://dx.doi.org/10.1016/S0263-7863(02)00112-6

Zhang, X., 2005. Critical Success Factors for Public-Private Partnerships in Infrastructure Development. Journal of Construction Engineering and Management, 131(1), pp.3-14. doi: http://dx.doi.org/10.1061/(ASCE)07339364(2005)131:1(71) and doi: http://dx.doi.org/10.1061/(ASCE)0733-9364(2005)131:1(3) 